\title{
MORPHOGENESIS OF Cynodon CULTIVARS FERTILIZED WITH NITROGEN
}

\author{
MORFOGÊNESE DE CULTIVARES DE Cynodon ADUBADAS COM \\ NITROGENNIO
}

\author{
Luiz Barreto de Morais NETO ${ }^{1}$; Maria Socorro de Souza CARNEIRO²; \\ Marcos Neves LOPES ${ }^{3}$; Magno José Duarte CÂNDIDO' ${ }^{4}$ Elzânia Sales PEREIRA ${ }^{2}$ \\ 1. Doutor em Zootecnia/Forragicultura; 2. Professora Doutora, Departamento de Zootecnia da Universidade Federal do Ceará - UFC, \\ Fortaleza, CE, Brasil; 3. Professor Doutor, Instituto Federal de Educação, Ciência e Tecnologia do Piauí - IFPI, Campus Valença do \\ Piauí, Valença do Piauí, PI, Brasil. marcos.neves@ifpi.edu.br; 4. Professor Doutor, Departamento de Zootecnia da Universidade Federal \\ do Ceará - UFC, Fortaleza, CE, Brasil.
}

\begin{abstract}
To evaluate the biomass flow of two cultivars of Cynodon (Tifton 85 grass and vaquero grass) fertilized with increasing levels of nitrogen (N) (control - without nitrogen; 200; 400 and $600 \mathrm{mg} \mathrm{dm}^{-3}$ ) under greenhouse conditions, this study was carried out, in a completely randomized design, with factorial arrangement. Forages were examined during three regrowth cycles, with results presented as mean values of the cycles. In the analysis of the effect of nitrogen fertilization, the Tifton 85 grass showed an increasing response to nitrogen levels for the leaf elongation rate (LER). The vaquero grass had a quadractic response for the LER with increasing levels of $\mathrm{N}$. As for the stem elongation rate, there was an increasing linear response in both grasses according to increasing levels of $\mathrm{N}$. The leaf senescence rate (LSR) of the Tifton 85 grass has been enhanced by nitrogen fertilization. The vaquero grass revealed a quadractic response for this variable LSR with nitrogen fertilization, with a minimum value of $0.96 \mathrm{~cm}_{\text {tiller }}^{-1}$ day $^{-1}$ with nitrogen level of $42.5 \mathrm{mg} \mathrm{dm}^{-3}$. The phyllochron and the total number of leaves of both grasses have been influenced by nitrogen fertilization, with downward and upward linear responses, respectively, with increasing levels of nitrogen. For the final mean leaf length (MLL) of both forages, we verified an increasing response with increasing levels of nitrogen. Tifton 85 grass and vaquero grass presented similar LER in the absence of nitrogen, but higher values were observed for the fertilized Tifton 85 grass. The fertilization using nitrogen leads to positive responses of the biomass flow of Tifton 85 grass and vaquero grass under the conditions of the present study.
\end{abstract}

KEYWORDS: Nitrogen fertilization. Biomass flow. Cynodon dactylon. Leaf elongation rate.

\section{INTRODUCTION}

Cynodon forages have great versatility for different production systems and can be used for grazing, stored or marketed. According to Pedreira (1996), this genus has important characteristics, such as the capacity to produce high amounts of good quality forage. The Vaquero is a cultivar which has among specific characteristics the advantage of being propagated by seeds, which facilitates its cultivation.

Souza et al. (2005) argued that for the intensive exploitation of pastures, correction and fertilization are among the factors determining the level of production in the summer. Fertilization, through its effect on the increase in biomass production, is desirable practice in increasing production and optimizing the use of pastures.

Among other factors, the nitrogen fertilization is important in determining the rate growth of grasses (FAGUNDES et al., 2005), in agreement with Mott, Quinn and Bisschoff (1970), the increased interest in nitrogenous fertilizers in tropical grasses occurs because nitrogen is often the first limiting factor in the production of these pastures.

The plant morphogenesis is defined as the dynamics of generation and expansion of the plant form in space (LEMAIRE; CHAPMAN, 1996), and as stated by Fagundes et al. (2005), is genetically programmed, but influenced by environmental factors such as temperature, water availability, nutrients, among others.

Studies of tissue flows through morphogenic processes come becoming an important tool for assessing the dynamics of leaves and tillers in forages (GARCEZ NETO et al., 2002). Some studies have been conducted to evaluate the morphogenesis in grasses and their relationship to fertilization (ALEXANDRINO et al., 2004; LOPES et al., 2013). Assessments on emergence of tillers (SBRISSIA et al., 2001) and leaves may help in understanding the relationship between grazing management and forage responses. 
This study aimed to evaluate the biomass flow of two cultivars of Cynodon (Tifton 85 grass and vaquero grass) under increasing levels of nitrogen.

\section{MATERIAL AND METHODS}

This research was undertaken in the period from August $10^{\text {th }}$ to December $16^{\text {th }}, 2011$, in a greenhouse owned by Integral Agroindustrial Ltd company, located in the Irrigação do Baixo Assu District (DIBA), in the municipality of Alto do Rodrigues, Rio Grande do Norte State.

The study consisted of eight treatments, two cultivars of Cynodon (Tifton 85 and Vaquero) and four nitrogen levels $(0,200,400$ and $600 \mathrm{mg} \mathrm{N} \mathrm{dm}$ $\left.{ }^{3}\right)$ equivalent to $0,400,800$ and $1200 \mathrm{~kg} \mathrm{~N} \mathrm{ha}^{-1} \mathrm{yr}^{-1}$, assigned to a randomized block design in a factorial arrangement (2 grasses by four nitrogen levels), with five replications, totaling 40 experimental units, with each pot representing an experimental unit.

The soil was classified as yellow ultisol (EMBRAPA, 1997), of franco sandy clay textural class type. The collection of soil for filling the pots was carried out in a homogeneous area, considering aspects such as: color, topography, texture and history of the area, which are carefully followed. Soil was collected at $0-20 \mathrm{~cm}$ layer. The soil was passed through a sieve of $4 \mathrm{~mm}$ mesh and subjected to drying in the greenhouse. Subsequently, pots with a capacity of $10 \mathrm{dm}^{3}$ received $10 \mathrm{~kg}$ of this soil for planting seedlings. A sample of this soil was sent to physical-chemical analysis and the results were as follows: $7 \mathrm{mg} \mathrm{dm}{ }^{-3} \mathrm{P} ; 0.80 \mathrm{cmol}_{\mathrm{c}} \mathrm{dm}^{-3} \mathrm{~K} ; 17 \mathrm{cmol}_{\mathrm{c}}$ $\mathrm{dm}^{-3} \mathrm{Ca}^{2+} ; 2 \mathrm{cmol}_{\mathrm{c}} \mathrm{dm}^{-3} \mathrm{Mg}^{2+} ; 0.0 \mathrm{cmol}_{\mathrm{c}} \mathrm{dm}^{-3} \mathrm{Al}^{3+}$; $8.5 \mathrm{mg} \mathrm{dm}^{-3} \mathrm{Na}^{+}$; $2.2 \%$ O.M.; SB $19.80 \mathrm{cmol}_{\mathrm{c}} \mathrm{dm}^{-3}$; CEC $20.60 \mathrm{cmol}_{\mathrm{c}} \mathrm{dm}^{-3} ; \mathrm{pH}$ in water 7.5; $7.5 \mathrm{mg} \mathrm{dm}^{-3}$ $\mathrm{Fe}^{2+} ; 0.5 \mathrm{mg} \mathrm{dm}^{-3} \mathrm{Cu}^{2+} ; 1.5 \mathrm{mg} \mathrm{dm}^{-3} \mathrm{Zn}^{2+}$ and 14.5 $\mathrm{mg} \mathrm{dm} \mathrm{dm}^{-3} \mathrm{Mn}$; coarse sand $11 \%$; fine sand $52.3 \%$; clay $28.7 \%$; silt $8 \%$. Then the necessary corrections were made, by applying $55 \mathrm{mg}_{2} \mathrm{O}_{5} \mathrm{dm}^{-3}$, in the form of single super phosphate, and $0.25 \mathrm{mg} \mathrm{dm}^{-3}$ FTE BR 12, for the supply of micronutrients.

In order to achieve greater uniformity between the two cultivars, planting was done in vegetative form, using rhizomes with 8 buds, which were placed into planting rows and completely covered with soil.

Irrigation management was based on the soil water retention curve, built before the start of the research at the Department of Agricultural Engineering, of the Federal University of Ceará UFC. The monitoring of soil moisture for replacement of irrigation was performed by 16 tensiometers, two per treatment. It was held daily irrigation, always keeping the value of soil moisture close to field capacity.

The uniformity cut was conducted at 45 days after planting, adopting the cutting height of 5 $\mathrm{cm}$ for both grasses, aiming to standardize the experimental units and eliminate the apical buds, causing thus a more intense tillering.

The nitrogen level for each treatment was divided into two portions; the first was applied soon after each cut, and the second in the half of the rest period, which was 28 days for both grasses. The nitrogen source used was ammonium sulfate.

We evaluated the following characteristics: leaf elongation rate (LER, cm til. ${ }^{-1}$ day $^{-1}$ ), stem elongation rate (SER, $\mathrm{cm}$ til. $^{-1} \mathrm{day}^{-1}$ ), leaf senescence rate (LSR, cm til. ${ }^{-1}$ day $\left.^{-1}\right)$, phyllochron $\left(\right.$ days leaf ${ }^{-1}$ ), total number of leaves per tiller (TNL, leaves tiller $\left.^{-1}\right)$ and average final length of the leaf blade (AFL, cm).

For monitoring morphogenic characteristics of forages over three regrowth cycles (regrowth 1, 2 and 3), we tagged three tillers per experimental unit. These tillers were evaluated every three days, recording the emergence, length of green and senescent fractions of leaf blades, according to Davies (1993) and the stem elongation, in order to estimate the respective rates. In those tillers, we recorded the total length and the length of the green portion of all leaf blades that were not completely dead from the ligule of the leaf itself, when expanded, or from the ligule of the most recently expanded leaf, in the case of emerging leaf. The length of the senescent portion was obtained by the difference between the total length of leaf blade and its portion still green. It was estimated the elongation of stems, as the difference of the height of the ligule farther from the stem base at the first and final reading, during the rest period.

Variables underwent analysis of variance and their mean values were compared by Tukey's test at 5\%probability, and for estimates of nitrogen level we applied a regression analysis using the statistical package SISVAR (FERREIRA, 1999).

\section{RESULTS AND DISCUSSION}

The response of Tifton 85 and vaquero grasses to nitrogen fertilization on the average of regrowth cycles (regrowth1, regrowth 2 and regrowth 3) for leaf elongation rate (LER), stem elongation rate (SER), leaf senescence rate (LSR), phyllochron, total number of leaves (TNL) and average final length of leaves (AFL) are listed in Table 1. 
Considering the effect of nitrogen fertilization, Tifton 85 grass showed an increasing response in the leaf elongation rate (LER) to nitrogen levels $(\mathrm{N})$. There was an increase in LER from 3.40 to $4.30 \mathrm{~cm}$ til. $^{-1}$ day $^{-1}$ for levels 0 and 600 $\mathrm{mg} \mathrm{dm}^{-3}$ nitrogen, respectively, with increase by
$26.47 \%$ at the level of $600 \mathrm{mg} \mathrm{dm}^{-3}$ nitrogen in relation to the absence of fertilization (Table 1). Hence, it can be inferred that vaquero grass showed low response in terms of leaf elongation to nitrogen fertilization, proving to be a grass poorly responsive to nitrogen.

Table 1. Morphogenic characteristics in Cynodon dactylon cv. Tifton 85 and cv. Vaquero according to nitrogen fertilization under greenhouse conditions.

\begin{tabular}{|c|c|c|}
\hline Grass & Variable & Equations (Nitrogen Effect) \\
\hline \multirow{6}{*}{ Tifton 85 grass } & $\begin{array}{l}\text { Leaf elongation rate } \\
\left(\text { LER, cm tiller-1 } \text { day }^{-1}\right)\end{array}$ & $\mathrm{LER}=3.40+0.0015^{* * \mathrm{~N}} ; \mathrm{R}^{2}=0.98$ \\
\hline & $\begin{array}{l}\text { Stem elongation rate } \\
\left(\mathrm{SER}, \mathrm{cm} \text { tiller }^{-1} \text { day }^{-1}\right)\end{array}$ & $\mathrm{SER}=0.41+0.0003 * \mathrm{~N} ; \mathrm{R}^{2}=0.84$ \\
\hline & $\begin{array}{l}\text { Leaf senescence rate } \\
\left(\mathrm{LSR}, \mathrm{cm}_{\text {tiller }}^{-1} \text { day }^{-1}\right)\end{array}$ & $\mathrm{LSR}=0.13+0.00007^{(\mathrm{ns})} \mathrm{N} ; \mathrm{R}^{2}=0.83$ \\
\hline & Phyllochron (days leaf ${ }^{-1}$ ) & $\mathrm{PHY}=1.57-0.0002 * * \mathrm{~N} ; \mathrm{R}^{2}=0.95$ \\
\hline & $\begin{array}{l}\text { Total number of leaves } \\
\text { (TNL, leaves tiller-1) }\end{array}$ & $\mathrm{TNL}=10.41+0.002 * * \mathrm{~N} ; \mathrm{R}^{2}=0.93$ \\
\hline & $\begin{array}{l}\text { Average final length of leaves } \\
\text { (AFL, cm) }\end{array}$ & $\mathrm{AFL}=5.25+0.001 * * \mathrm{~N} ; \mathrm{R}^{2}=0.98$ \\
\hline \multirow{6}{*}{ Vaquero grass } & $\begin{array}{l}\text { Leaf elongation rate } \\
\left(\text { LER, cm tiller-1 } \text { day }^{-1}\right)\end{array}$ & $\begin{array}{c}\mathrm{LER}=3.72+0.0012 * \mathrm{~N}-0.00001 * \mathrm{~N}^{2} \\
\mathrm{R}^{2}=0.69\end{array}$ \\
\hline & $\begin{array}{l}\text { Stem elongation rate } \\
\left(\mathrm{SER}, \mathrm{cm}_{\text {tiller }}^{-1} \mathrm{day}^{-1}\right)\end{array}$ & $\mathrm{SER}=1.65+0.0005 * * \mathrm{~N} ; \mathrm{R}^{2}=0.86$ \\
\hline & $\begin{array}{l}\text { Leaf senescence rate } \\
\left(\mathrm{LSR}, \mathrm{cm} \text { tiller }^{-1} \mathrm{day}^{-1}\right)\end{array}$ & $\begin{array}{l}\mathrm{LSR}=0.98-0.00085^{*} \mathrm{~N}+ \\
0.00001^{(\mathrm{ns})} \mathrm{N}^{2} ; \mathrm{R}^{2}=0.89\end{array}$ \\
\hline & Phyllochron (days leaf ${ }^{-1}$ ) & $\mathrm{PHY}=0.91-0.00004^{(\mathrm{ns})} \mathrm{N} ; \mathrm{R}^{2}=0.50$ \\
\hline & $\begin{array}{l}\text { Total number of leaves } \\
\left.\text { (TNL, leaves tiller }{ }^{-1}\right)\end{array}$ & $\mathrm{TNL}=19.90+0.0019 * * \mathrm{~N} ; \mathrm{R}^{2}=0.64$ \\
\hline & $\begin{array}{l}\text { Average final length of leaves } \\
\text { (AFL, cm) }\end{array}$ & $\mathrm{AFL}=2.91+0.00003^{(\mathrm{ns})} \mathrm{N} ; \mathrm{R}^{2}=0.91$ \\
\hline
\end{tabular}

The increase in leaf elongation rate of the Tifton 85 grass with increasing doses of nitrogen corroborates the response of that variable observed by Pereira et al. (2011) who examined the Tifton 85 grass under nitrogen fertilization. This demonstrates the significant role of this nutrient on the behavior of this variable (ALEXANDRINO et al., 2004; FAGUNDES et al., 2005; LOPES et al., 2013), which can be mainly attributed to the increase in production of cells (cell division), (VOLENEC; NELSON, 1984), reflecting the deposition of nutrients, especially nitrogen on areas of elongation and cell division (SKINNER; NELSON, 1995). Also, according to Fagundes et al. (2005), the increase in leaf elongation rate with nitrogen fertilization can be ascribed to the significant influence of nitrogen on plant physiological processes, reflecting an increase in leaf growth. In this context, it is worth noting the influence of nitrogen fertilization on the plant gas exchange, providing increased photosynthetic rate at high levels of nitrogen (POMPEU et al., 2010; LOPES et al., 2011).

The leaf elongation rate is a variable of utmost importance in the biomass flow of forage, because it is directly related to biomass production of forage. As the LER is increased, there is an increase in the proportion of leaves and, consequently, more photosynthetically active leaf area, promoting greater accumulation of biomass, probably by the best carbon: nitrogen ratio for plant regrowth.

When analyzed the stem elongation rate, it was verified an increasing linear response for both grasses according to increasing nitrogen levels, with estimated values of 0.41 and $0.59 \mathrm{~cm} \mathrm{til.}^{-1}$ day $^{-1}$ (Tifton 85 grass) and 1.65 and $1.95 \mathrm{~cm} \mathrm{til.}^{-1}$ day $^{-1}$ (vaquero grass) for the nitrogen levels of 0 and 600 $\mathrm{mg} \mathrm{dm}{ }^{-3}$, respectively (Table 1 ). This increase in stem elongation reflects a favorable effect of nitrogen on plant growth, with higher horizontal growth, provided by the development of rhizomes, 
which advances in growth in response to a canopy closure.

The stem elongation is a morphogenic characteristic of forage grasses with proven relevance for the sward growth, as it ensures the maintenance of canopy architecture when it achieves a higher biomass, while maintaining an adequate distance between the leaves and avoiding increase in light extinction coefficient (SUGIYAMA et al., 1985). On the other hand, stand out the negative effects provided by the increase in stem component in total biomass, with a direct impact on the quality of produced forage by the reduction in the leaf/stem ratio, reducing thus the nutritional value of the biomass produced (CÂNDIDO et al., 2006; SILVA et al., 2007a) and in its use by grazing animals (SILVA et al., 2007b).

The leaf senescence rate (LSR) of Tifton 85 grass was increased by nitrogen fertilization (Table 1), revealing estimated values of 0.13 and $0.17 \mathrm{~cm}$ til. $^{-1}$ day $^{-1}$ for nitrogen levels of 0 and $600 \mathrm{mg} \mathrm{dm}^{-3}$, respectively (Table 1), reflecting the shorter life of the first leaves. Thus, it is noteworthy that the plant growth rhythm responding to increasing levels of nitrogen, with high rates of leaf appearance and elongation, promotes senescence of first formed leaves, since it increases competition for assimilates (GOMIDE et al., 2003). The vaquero grass showed a quadratic response of LSR to nitrogen fertilization, with minimum value of $0.96 \mathrm{~cm}$ til. ${ }^{-1}$ day $^{-1}$ in the nitrogen level of $42.5 \mathrm{mg} \mathrm{dm}^{-3}$, being increased at higher levels of nitrogen.

Phyllochron and total number of leaves of Tifton 85 and vaquero grasses were influenced by nitrogen fertilization, with a decreasing and increasing linear response, respectively, with the increase in nitrogen (Table 1). For phyllochron, estimated values were 1.57 and 1.45 days leaf $^{-1}$ (Tifton 85 grass) and 0.91 and 0.89 days leaf ${ }^{-1}$ (vaquero grass) in the nitrogen levels of 0 and 600 $\mathrm{mg} \mathrm{dm}^{-3}$, respectively. Estimated values for the total number of leaves were 10.4 and 11.6 leaves tiller $^{-1}$ (Tifton 85 grass) and 19.9 and 21.0 leaves tiller $^{-1}$ (vaquero grass) in the nitrogen levels of 0 and 600 $\mathrm{mg} \mathrm{dm}{ }^{-3}$, respectively (Table 1 ).

The response of phyllochron of both forages as well as reported in the literature (SILVA et al., 2009; POMPEU et al., 2010; PEREIRA et al., 2011; LOPES et al., 2013) indicated the relevance of nitrogen fertilization in shortening the time required for the emergence of leaves in the tiller, since it increases the production of new cells (VOLENEC; NELSON, 1984), with a positive effect in leaf production of forage grasses. With this, the increase in nitrogen levels can anticipate the entry of grazing animals and may result in a greater number of grazing cycles during the year for pastures fertilized with higher levels of nitrogen (LOPES et al., 2013).

In this context, it is relevant to observe that the reduction of phyllochron with increasing nitrogen levels stems from the effect of this nutrient on growth rates, especially the leaf growth (GARCEZ NETO et al., 2002), giving to pastures a greater ability to reconstitute the leaf area. Consequently there will be a greater potential for regrowth, since after defoliation a rapid recovery of photosynthetic apparatus enables greater competitive ability of individuals in the plant community (MARTUSCELLO et al., 2006). Thus, nitrogen takes a key role for promoting this recovery, because it is an essential nutrient in several physiological processes of forages, contributing positively in the gas exchange of forage plants, as verified by Pompeu et al. (2010), who studied aruana grass fertilized with nitrogen and by Lopes et al. (2011) that worked with increasing levels of nitrogen on massai grass.

With regard to the total number of green leaves per tiller, it is of paramount importance to consider that this characteristic expresses the potential for carbon assimilation and forage production at the level of tiller. It is an important variable in the evaluation and management of forage plants, because it is the component of biomass with best qualitative attribute, being the fraction most preferred by grazing animals, and because of its use as a criterion for determining the resting period in a pasture area (FULKERSON; DONAGHY, 2001).

Increased nitrogen fertilization can anticipate the entry of grazing animals because favors the biomass flow in forage plants (LOPES et al., 2013). In this way, the definition of timing defoliation should be based on the management adopted in the pasture, showing the forage physiology, however, the nitrogen will interfere with this time because of the influence on morphophysiology of the plant.

For the average final length of leaves (AFL) of the two forages, we observed an increasing response with increasing levels of nitrogen (Table 1). An increase was detected for the AFL from 5.25 and $5.85 \mathrm{~cm}$ for Tifton 85 and from 2.91 to $2.93 \mathrm{~cm}$ at levels of 0 and $600 \mathrm{mg} \mathrm{d^{-3 }}$ nitrogen, respectively. It was registered an increase of $11.43 \%$ for Tifton 85 grass at $600 \mathrm{mg} \mathrm{dm}^{-3}$ nitrogen in relation to the absence of fertilization. This can be especially attributed to the increase in leaf elongation rate with nitrogen fertilization (PEREIRA et al., 2011; LOPES et al., 2013), which contributed to the reconstitution of leaf area after 
cutting, critical to maintaining the continuity of pasture (ALEXANDRINO et al., 2004).

The unfolding of the factor grass (Tifton 85 and vaquero grasses) at each nitrogen level for the variables: leaf elongation rate (LER), stem elongation rate (SER), leaf senescence rate (LSR), phyllochron, total number of leaves (TNL) and average final length of leaves (AFL) are listed in Tables 2 and 3.

Tifton 85 and vaquero grasses presented similar LER in the absence of nitrogen, but fertilized plants showed higher values for the Tifton 85 grass (Table 2), evidencing to be the most responsive to nitrogen fertilization. For SER and LSR there were differences between forages for all levels examined, with higher values for the vaquero grass (Table 2). The highest SER of vaquero grass compared with Tifton 85 grass for all nitrogen levels reflects the pronounced growth in terms of stem, in response to intense production of rhizomes, a characteristic revealed by the forage for a greater soil cover which associated with the reduction in light penetration inside the canopy, possibly has triggered shoot elongation by means of etiolation. The highest LSR of vaquero grass in relation to Tifton 85 grass for all nitrogen levels is justified by the faster growth of that grass, causing a spontaneous senescence, as the life span of the first leaves reaches the end.

Table 2. Morphogenic characteristics in Cynodon dactylon cv. Tifton 85 and cv. Vaquero at each level of nitrogen fertilization examined under greenhouse conditions.

\begin{tabular}{cccc}
\hline \multirow{2}{*}{ Variable } & $\begin{array}{c}\text { Nitrogen level } \\
\left(\mathrm{mg} \mathrm{dm}^{-3}\right)\end{array}$ & Tifton 85 grass & Grass \\
\cline { 3 - 4 } & 0 & $3.38 \mathrm{a}$ & $3.80 \mathrm{a}$ \\
LER & 200 & $3.97 \mathrm{a}$ & $3.21 \mathrm{~b}$ \\
$\left(\mathrm{~cm} \mathrm{tiller}^{-1}\right.$ day $\left.^{-1}\right)$ & 400 & $4.72 \mathrm{a}$ & $3.84 \mathrm{~b}$ \\
& 600 & $5.12 \mathrm{a}$ & $4.09 \mathrm{~b}$ \\
\hline & 0 & $0.40 \mathrm{~b}$ & $1.75 \mathrm{a}$ \\
SER & 200 & $0.49 \mathrm{~b}$ & $1.74 \mathrm{a}$ \\
$\left(\mathrm{cm} \mathrm{tiller}^{-1}\right.$ day $\left.^{-1}\right)$ & 400 & $0.73 \mathrm{~b}$ & $2.01 \mathrm{a}$ \\
& 600 & $0.70 \mathrm{~b}$ & $2.38 \mathrm{a}$ \\
\hline & 0 & $0.80 \mathrm{~b}$ & $1.13 \mathrm{a}$ \\
LSR & 200 & $0.79 \mathrm{~b}$ & $1.02 \mathrm{a}$ \\
$\left(\mathrm{cm} \mathrm{tiller}^{-1}\right.$ day $\left.^{-1}\right)$ & 400 & $0.81 \mathrm{~b}$ & $1.06 \mathrm{a}$ \\
& 600 & $0.83 \mathrm{~b}$ & $1.14 \mathrm{a}$ \\
\hline
\end{tabular}

Leaf elongation rate (LER), stem elongation rate (SER) and leaf senescence rate (LSR); means followed by similar letters in the same row (lower cases) are not significantly different $(\mathrm{P}>0.05)$ by Tukey's test.

Table 3. Structural characteristics of Cynodon dactylon cv. Tifton 85 and cv. Vaquero according to regrowth cycles under greenhouse conditions.

\begin{tabular}{|c|c|c|c|}
\hline \multirow{2}{*}{ Variable } & \multirow{2}{*}{$\begin{array}{l}\text { Nitrogen level } \\
\left(\mathrm{mg} \mathrm{dm}^{-3}\right)\end{array}$} & \multicolumn{2}{|c|}{ Grass } \\
\hline & & Tifton 85 grass & Vaquero grass \\
\hline \multirow{4}{*}{$\begin{array}{l}\text { Phyllochron } \\
\text { (days leaf }^{-1} \text { ) }\end{array}$} & 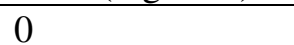 & $1.57 \mathrm{a}$ & $0.90 \mathrm{~b}$ \\
\hline & 200 & $1.50 \mathrm{a}$ & $0.93 \mathrm{~b}$ \\
\hline & 400 & $1.36 \mathrm{a}$ & $0.87 \mathrm{~b}$ \\
\hline & 600 & $1.33 \mathrm{a}$ & $0.86 \mathrm{~b}$ \\
\hline \multirow{4}{*}{$\begin{array}{c}\text { TNL } \\
\left(\text { leaves tiller }^{-1} \text { ) }\right.\end{array}$} & 0 & $10.40 \mathrm{~b}$ & $20.51 \mathrm{a}$ \\
\hline & 200 & $11.02 \mathrm{~b}$ & $20.13 \mathrm{a}$ \\
\hline & 400 & $12.42 \mathrm{~b}$ & $20.71 \mathrm{a}$ \\
\hline & 600 & $12.62 \mathrm{~b}$ & $22.89 \mathrm{a}$ \\
\hline \multirow{4}{*}{ AFL $(\mathrm{cm})$} & 0 & $5.19 \mathrm{a}$ & $3.07 \mathrm{~b}$ \\
\hline & 200 & $5.74 \mathrm{a}$ & $2.67 \mathrm{~b}$ \\
\hline & 400 & $6.22 \mathrm{a}$ & $3.00 \mathrm{~b}$ \\
\hline & 600 & $6.49 \mathrm{a}$ & $3.00 \mathrm{~b}$ \\
\hline
\end{tabular}

Total number of leaves (TNL) and average final lenght of leaves (AFL); means followed by similar letters in the same row (lower cases) are not significantly different $(\mathrm{P}>0.05)$ by Tukey's test. 
The Tifton 85 grass had higher phyllochron compared with vaquero grass for all nitrogen levels studied (Table 3). The lowest value of phyllochron was observed for vaquero grass, regardless of nitrogen levels, indicating the different genetics of grasses. The vaquero grass presented a reduction in the time of appearance of leaves in the tiller, possibly due to greater production of cells, which contributes positively to leaf production. The grass vaquero revealed an important feature for pasture management, since it can anticipate the entry of grazing animals, which may result in a higher number of cycles during the year for the pastures managed similarly.

The vaquero grass presented greater TNL in comparison with Tifton 85 grass for all nitrogen levels (Table 3). This result was due to the reduced phyllochron of the vaquero grass, which combined with the greater production of rhizomes, resulted in a greater TNL for plants of vaquero grass at the same cutting interval.
The Tifton 85 grass exhibited greater AFL for all nitrogen levels (Table 3), which can be related to the superiority in LER of the Tifton 85 grass, proving to be a grass that gives priority to the production of leaves, unlike to that found for the vaquero grass, highlighting the increase in stem compared with Tifton 85 grass.

\section{CONCLUSIONS}

Nitrogen fertilization provides positive responses about the flow of biomass of Tifton 85 and vaquero grasses under the conditions of the present study.

The vaquero grass was superior to Tifton 85 in characteristics of stem elongation, leaf senescence and total number of leaves in the nitrogen levels studied.

The Tifton 85 grass was superior as for leaf elongation, phyllochron, and length of leaves in the levels examined.

RESUMO: Objetivou-se avaliar o fluxo de biomassa de dois cultivares do gênero Cynodon (capimTifton 85 e capim-vaquero) adubados com doses crescentes de nitrogênio $(\mathrm{N})$ (controle - sem nitrogênio; 200; 400 e $600 \mathrm{mg} \mathrm{dm}^{-3}$ ) em condições de casa de vegetação, em um delineamento inteiramente casualizado, em arranjo fatorial. As forrageiras foram estudas durante três ciclos de rebrotação, com os resultados apresentados na média dos ciclos. No estudo do efeito da adubação nitrogenada, o capim-Tifton 85 apresentou para a taxa de alongamento foliar (TAlF) resposta crescente às doses de N. O capim-vaquero apresentou resposta quadrática para TAlF com o incremento das doses de N. Analisando-se a taxa de alongamento dos colmos, verificou-se resposta linear crescente para ambas as gramíneas com o aumento das doses de nitrogênio. A taxa de senescência foliar (TSF) do capim-Tifton 85 foi incrementada pela adubação nitrogenada. $\mathrm{O}$ capim-vaquero revelou para TSF resposta quadrática com a adubação nitrogenada, com valor mínimo de $0,96 \mathrm{~cm}$ perf $^{-1}$ dia $^{-1}$ na dose de nitrogênio de $42,5 \mathrm{mg} \mathrm{dm}^{-3}$. O filocrono e o número total de folhas do capim-Tifton 85 e do capimvaquero foram influenciados pela adubação nitrogenada, revelando resposta linear decrescente e crescente, respectivamente, com o incremento nas doses de nitrogênio. Para o comprimento médio final das folhas (CMF) das duas forrageiras, constatou-se resposta crescente com a elevação nas doses de nitrogênio. Os capins-Tifton 85 e vaquero apresentaram TAlF semelhante na ausência de nitrogênio, porém para as plantas adubadas verificou-se valores superiores para o capim-Tifton 85 . A adubação nitrogenada proporciona respostas positivas sobre o fluxo de biomassa dos capins-Tifton 85 e vaquero nas condições do presente estudo.

PALAVRAS-CHAVE: Adubação nitrogenada. Fluxo de biomassa. Cynodon dactylon. Taxa de alongamento foliar.

\section{REFERENCES}

ALEXANDRINO, E.; NASCIMENTO JÚNIOR, D.; MOSQUIM, P. R.; REGAZZI, A. J.; ROCHA, F. C. Características morfogênicas e estruturais na rebrotação da Brachiaria brizantha cv. Marandu submetida a três doses de nitrogênio. Revista Brasileira de Zootecnia, Viçosa, v. 33, n. 6, p. 1372-1379, 2004. http://doi: 10.5433/1679-0359.2014v35n5p2673

CÂNDIDO, M. J. D.; SILVA, R. G.; NEIVA, J. N. M.; FACÓ, O.; BENEVIDES, Y. I.; FARIAS, S. F. Fluxo de biomassa em capim-tanzânia pastejado por ovinos sob três períodos de descanso. Revista Brasileira de Zootecnia, Viçosa, v.35, n. 6, p. 2234-2242, 2006. http://dx.doi.org/10.1590/S1516-35982006000800006 
DAVIES, A. Tissue turnover in the sward. In: DAVIES, A.; BAKER, R. D.; GRANT, S. A. et al. (Eds.). Sward measurement handbook. 2.ed. Reading: British Grassland Society, 1993. p. 183-216.

EMBRAPA - Empresa Brasileira de Pesquisa Agropecuária. Manual de métodos de análises do solo. 2.ed. Versão atualizada. Rio de Janeiro: CNPS, 1997. 212 p.

FAGUNDES, J. L.; FONSECA, D. M.; GOMIDE, J. A.; NASCIMENTO JUNIOR, D.; VITOR, C. M. T.; MORAIS, R. V.; MISTURA, C.; REIS, G. C.; MARTUSCELLO, J. A. Acúmulo de forragem em pastos de Brachiaria decumbens adubados com nitrogênio. Pesquisa Agropecuária Brasileira, Brasília, v. 40, n. 4, p. 397-403, 2005. http://dx.doi.org/10.1590/S0100-204X2005000400012

FULKERSON, W. J.; DONAGHY, D. J. Plant soluble carbohydrate reserves and senescence - key criteria for developing an effective grazing management system for ryegrass based pasture: a review. Australian Journal Experimental Agriculture, Collingwood, v. 41, n. 2, p. 261-275, 2001. https://doi.org/10.1071/EA00062

GARCEZ NETO, A. F.; NASCIMENTO JÚNIOR, D.; REGAZZI, A. J.; FONSECA, D. M.; MOSQUIM, P. R.; GOBBI, K. F. Respostas morfogênicas e estruturais de Panicum maximum cv. Mombaça sob diferentes níveis de adubação nitrogenada e alturas de corte. Revista Brasileira de Zootecnia, Viçosa, v.31, n. 5, p. 1890-1900, 2002. http://dx.doi.org/10.1590/S1516-35982002000800004

LEMAIRE, G.; CHAPMAN, D. F. Tissue flows in grazed plant communities. In: HODGSON, J.; ILLIUS, A. W. (Eds.). The ecology and management of grazing systems. Wallingford, UK: CAB International, 1996. p. 3-36.

LOPES, M. N.; LACERDA, C. F.; CÂNDIDO, M. J. D.; POMPEU, R. C. F. F.; SILVA, R. G.; LOPES, J. W. B.; FERNANDES, F. R. B.; BEZERRA, F. M. L. Gas exchange in massai grass under five nitrogen fertilization levels during establishment and regrowth. Revista Brasileira de Zootecnia, Viçosa, v. 40, n. 9, p. 1862-1869, 2011b. http://dx.doi.org/10.1590/S1516-35982011000900004

LOPES, M. N.; CÂNDIDO, M. J. D.; POMPEU, R. C. F. F.; SILVA, R. G.; CARVALHO, T. C. F.; SOMBRA, W. A.; MORAIS NETO, L. B.; PEIXOTO, M. J. A. Biomass flow in massai grass fertilized with nitrogen under intermittent stocking grazing with sheep. Revista Brasileira de Zootecnia, Viçosa, v. 42, n. 1, p.13-21, 2013. http://dx.doi.org/10.1590/S1516-35982013000100003

MARTUSCELLO, J. A.; FONSECA, D. M.; NASCIMENTO JÚNIOR, D.; SANTOS, P. M.; CUNHA, D. N. F. V.; MOREIRA, L. M. Características morfogênicas e estruturais de capim-massai submetido a adubação nitrogenada e desfolhação. Revista Brasileira de Zootecnia, Viçosa, v. 35, n. 3, p. 665-671, 2006. http://dx.doi.org/10.1590/S1516-35982006000300006

MOTT, G. O.; QUINN, L. R.; BISSCHOFF, W. V. A. The retention of nitrogen in a soil-plant-animal system in guinea grass (Panicum maximum) pastures in Brazil. In: INTERNATIONAL GRASSLANDS CONGRESS, 10., 1970. Proceedings. Surfers Paradise: University of Quensland Press, 1970. p. 414-416.

PEDREIRA, C. G. S. Avaliação de novas gramíneas do gênero Cynodon para a pecuária do sudeste dos Estados Unidos. In: WORKSHOP SOBRE O POTENCIAL FORRAGEIRO DO GÊNERO CYNODON, 1996, Juiz de Fora. Anais... Juiz de Fora: Embrapa-CNPGL, 1996. p. 111-125.

PEREIRA, O. G.; ROVETTA, R.; RIBEIRO, K. G.; SANTOS, M. E. R.; FONSECA, D. M.; CECON, P. R. Características morfogênicas e estruturais do capim-tifton 85 sob doses de nitrogênio e alturas de corte. Revista Brasileira de Zootecnia, Viçosa, v. 40, n. 9, p. 1870-1878, 2011. http://dx.doi.org/10.1590/S151635982011000900005

POMPEU, R. C. F. F.; CÂNDIDO, M. J. D.; LOPES, M. N.; GOMES, F. H. T.; LACERDA, C. F.; AQUINO, B. F.; MAGALHÃES, J. A. Características morfofisiológicas do capim-aruana sob diferentes doses de nitrogênio. Revista Brasileira de Saúde e Produção Animal, Salvador, v. 11, p. 1187-1210, 2010. 
SBRISSIA, A. F.; DA SILVA, S. C.; CARVALHO, C. A. B.; CARNEVALLI, R. A.; PINTO, L. F. M.; FAGUNDES, J. L.; PEDREIRA, C. G. S. Tiller size/population density compensation in grazed coastcross bermudagrass swards. Scientia Agricola, Piracicaba, v. 58, n. 4, p. 655-665, 2001. http://dx.doi.org/10.1590/S0103-90162001000400002

SILVA, R. G.; CÂNDIDO, M. J. D.; NEIVA, J. N. M.; LÔBO, R. N. B.; SILVA, D. S. Características estruturais do dossel de pastagens de capim-tanzânia mantidas sob três períodos de descanso com ovinos. Revista Brasileira de Zootecnia, Viçosa, v. 36, n. 5, p. 1255-1265, 2007a. http://dx.doi.org/10.1590/S151635982007000600006

SILVA, R. G.; NEIVA, J. N. M.; CÂNDIDO, M. J. D.; LÔBO, R. N. B. Aspectos comportamentais e desempenho produtivo de ovinos mantidos em pastagens de capim-tanzânia manejado sob lotação intermitente. Ciência Animal Brasileira, Goiânia, v. 8, n. 4, p. 609-620, 2007 b.

SILVA, C. C. F.; BONOMO, P.; PIRES, A. J. V.; MARANHÃO, C. M. A.; PATÊS, N. M. S.; SANTOS, L. C. Características morfogênicas e estruturais de duas espécies de braquiária adubadas com diferentes doses de nitrogênio. Revista Brasileira de Zootecnia, Viçosa, v.38, n. 4, p.657-661, 2009.

http://dx.doi.org/10.1590/S1516-35982009000400010

SKINNER, R. H.; NELSON, C. J. Elongation of the grass leaf and its relationship to the phyllochron. Crop Science, Madison, v.35, n. 1, p.4-10, 1995. http://dx. doi.org/ 10.2135/cropsci1995.0011183X003500010002x

SOUZA, E. M.; ISEPON, O. J.; ALVES, J. B.; BASTOS, J. F. P.; LIMA, R. C. Efeitos da irrigação e adubação nitrogenada sobre a massa de forragem de cultivares de Panicum maximum Jacq. Revista Brasileira de Zootecnia, v. 34, n. 4, p. 1146-1155, 2005. http://dx.doi.org/10.1590/S1516-35982005000400008

SUGIYAMA, S.; YONEYAMA, M.; TAKAHASHI, N.; GOTOH, K. Canopy structure and productivity of Festuca arundinaceae Schreb, swards during vegetative and reproductive growth. Grass and Forage Science, Oxford, v.40, n. 1, p. 49-55, 1985. https://doi.org/10.1111/j.1365-2494.1985.tb01719.x

VOLENEC, J. J.; NELSON, C. J. Carbohydrate metabolism in leaf meristems of tall fescue. II. Relationship to leaf elongation rates modified by nitrogen fertilization. Plant Physiology, Waterbury, v. 74, n. 3, p. 595-600, 1984. https://doi.org/10.1104/pp.74.3.590 